\title{
NEW TO NEW ZEALAND DETECTION OF COMMON SMUT OF CORN (USTILAGO MAYDIS) FROM A SINGLE CORNFIELD IN GISBORNE
}

\author{
K.J. FROUD ${ }^{1}$, M.S. BULLIANS ${ }^{1}$, M. BRAITHWAITE ${ }^{2}$, \\ M.F.S.W. FERNANDO ${ }^{1}$, C.F. HILL ${ }^{1}$ and R. MIDGLEY ${ }^{3}$ \\ ${ }^{I}$ Ministry of Agriculture and Forestry, PO Box 2095, Auckland, New Zealand \\ ${ }^{2}$ Ministry of Agriculture and Forestry, PO Box 24, Lincoln, New Zealand \\ ${ }^{3}$ AgriQuality, PO Box 646, Gisborne, New Zealand \\ Corresponding author: froudk@maf.govt.nz
}

On 13 January 2006, the MAF Investigation and Diagnostic Centre (IDC) was alerted by a corn seed-crop manager to a possible new to New Zealand corn disease in Gisborne. Samples were immediately collected by IDC and identified as the Basidiomycete fungus Ustilago maydis Corda, which was later validated by Landcare Research. A survey of the field showed that symptomatic plants were concentrated to five rows in the field's south-east corner. Symptomatic plants observed in the field were immediately removed and destroyed. A delimiting survey of associated Zea mays crops showed no further infection in the region. Remaining plants in the original field were cut and processed into silage to kill any spores. The field was then cross-sown with ryegrass to minimise disease spread. Machinery used on the property was traced for cleaning and disinfection. The likely pathway of entry to New Zealand was considered to be contaminated seed. Library seeds of all seed-lines of interest were tested by IDC, and spores of the correct dimensions and morphology for U. maydis were detected in all samples. However, the majority of spores were considered non-viable due to heavy loading of fungicide on the seeds. Further organism management and surveillance actions are planned for spring 2006.

\section{WHEAT STREAK MOSAIC VIRUS (WSMV) DETECTION IN NEW ZEALAND WHEAT CROPS}

\author{
R.A. LISTER ${ }^{1}$, J.D.F. FLETCHER ${ }^{1}$, S.L. BITHELL ${ }^{1}$, \\ F.M. OCHOA-CORONA ${ }^{2}$ and G.M. BURNIP ${ }^{3}$ \\ ${ }^{I}$ Crop \& Food Research, Private Bag 4704, Christchurch, New Zealand \\ ${ }^{2}$ Ministry of Agriculture and Forestry, PO Box 2095, Auckland, New Zealand \\ ${ }^{3}$ Ministry of Agriculture and Forestry, PO Box 24, Lincoln, New Zealand
}

Corresponding author: listerr@crop.cri.nz

Wheat streak mosaic virus (WSMV) is considered a serious pathogen of wheat in North America and caused considerable damage to wheat crops in Australia last season. In August 2005, grain from New Zealand was tested at CSIRO, Canberra, for WSMV, and found to be positive. This result was confirmed by PCR and sequencing. The positives were in two reserve Canadian samples and one New Zealand line. The New Zealand line, 6065.3, was developed over 10 years ago, but is not yet commercially released. This was the first record of WSMV in New Zealand. During the summer of 2005/2006, an extensive survey of three cereal performance trials (CPT) and 105 South Island commercially grown wheat crops was undertaken to determine the distribution of WSMV infection. Testing was by ELISA and PCR. WSMV was found at each of the CPT sites and in 25 commercially grown wheat crops (24\% of those tested). The areas corresponding to WSMV infection are Methven, Norwood, Wakanui near Ashburton, Chertsey, Mt Somers, Hinds and Waihao. In total, 52 cultivars (CPT and commercial) were sampled and of these $23(44 \%)$ tested positive for WSMV. These results suggest that WSMV is widely distributed temporally, geographically and within cultivars. 